\title{
Implementation of Business Process Reengineering (BPR): Case Study of Official Trip Procedures in Higher Education Institutions
}

\author{
Rina Djunita Pasaribu ${ }^{1}$ (D), Grisna Anggadwita ${ }^{1}$ (D) Ratih Hendayani ${ }^{1}$ (D), \\ Raswyshnoe Boing Kotjoprayudi²(iD), Dessy Indah Nur Apiani ${ }^{3}$ \\ ${ }^{1}$ School of Economics and Business, Telkom University (Indonesia) \\ ${ }^{2}$ School of Applied Science, Telkom University (Indonesia) \\ ${ }^{3}$ Directorate of Secretariat \& Strategic Planning, Telkom University (Indonesia) \\ rinadjunita@telkomuniversity.ac.id, grisnaanggadwita@telkomuniversity.ac.id, ratibhendayani@telkomuniversity.ac.id, \\ raswyshnoe@telkomuniversity.ac.id, dessyindah@telkomuniversity.ac.id
}

Received: November 2020

Accepted: June 2021

\section{Abstract:}

Purpose: Official trip is one of the common business processes carried out by every organization, including educational institutions. However, in its implementation, there are various kinds of obstacles that have an impact on the lack of effectiveness and efficiency of the system, in terms of time, material and human resources. This study aims to evaluate existing business processes and design, and implement the results of business process re-engineering (BPR) in the official trip system which is supported by digitization and digitalization with a multi-unit integration approach at one of the private universities in Indonesia, Telkom University.

Design/methodology/approach: This study uses a mixed-method with an embedded design approach. The quantitative method was carried out by calculating the performance of official trip procedures before and after the BPR. Meanwhile, the qualitative method was carried out by conducting interviews and Focus Group Discussions (FGD) with key informants in this study. Triangulation technique was used to validate the research results.

Findings: The BPR process has resulted in radical changes to the official trip system at the university, namely from a mixed system of manual/offline \& online to completely online, from a very centralized to decentralized decision process, and the availability of a transparent monitoring system. These changes provide significant results by increasing the effectiveness and efficiency of business processes so as to speed up time, save paper (reduce paper waste and reduce costs) and optimize employee assignments.

Originality/value: This study adds new insights into the implementation of BPR to the official trip system in higher education. This research implies that BPR can produce radical changes in business processes in higher education to become more effective and efficient. In addition, this study proposes several practical and academically useful recommendations for further research in this area.

Keywords: BPR, digitalization, digitization, industry 4.0, official trip, online SPPD, higher education 


\section{To cite this article:}

Pasaribu, R.D., Anggadwita, G., Hendayani, R., Kotjoprayudi, R.B., \& Apiani, D.I.N. (2021). Implementation of Business Process Reengineering (BPR): Case study of official trip procedures in higher education institutions. Journal of Industrial Engineering and Management, 14(3), 622-644. https://doi.org/10.3926/jiem.3403

\section{Introduction}

The development of information technology has been used to break down communication barriers between organizational functions. The development of technology in the industrial 4.0 eras has become an important supporter in improving business processes through digitization and digitalization. Thus, organizations focus on developing more flexible, coordinated, collaborative, and communicative capabilities (Al-Mashari, Irani \& Zairi, 2001; Attaran, 2003; Terziovski, Power \& Sohal, 2003). Most organizations have paid particular attention to "processes" in recent years (Valiris \& Glykas, 2004), including institutions of higher education. BPR may seem foreign to the organizational culture of higher education, but nowadays many educational institutions are involved in reengineering business processes and other management concepts (Birnbaum, 1988), especially those related to administrative processes. The official trip system is one of the business processes that are carried out in almost every company or institution. Increasing efficiency and effectiveness in the payment of official trip expenses is needed to support the implementation of duties and work unit functions.

BPR is a management tool, in which business processes are examined and redesigned to improve cost efficiency and service effectiveness (Lindsay, Downs \& Lunn, 2003; Vidovic \& Vuksic, 2003). Based on the latest management concepts, reengineering are needed to facilitate processes across organizational boundaries and integrate back-and front-office processes (Fadel \& Tanniru, 2005; Lin, Yang \& Pai, 2002). Higher education performance is very important for the country's competitiveness (Porter, 1990). Higher education institutions have invested heavily in business process reengineering by leveraging information technology to improve services and reduce costs in several areas including finance, human resources, business intelligence, teaching and learning, advancement, and student services (Educause, 2005). Penrod and Dolence (1992) viewed reengineering as a suitable way to ensure higher education institutions adapt to the changing demands placed on them. Management complexity in higher education institutions demands effectiveness and efficiency in administrative processes, not only in education and teaching services.

Official trip is an important and inseparable part; this expenditure budget is productive and is a priority in its use. The official trip system in tertiary institutions involves various units so that it has an impact on the slow process of disbursement of fees received by employees. In fact, employees have to go on business trips using personal costs in advance when departing. The process of disbursing funds that takes a long time has an impact on employee performance and causes reluctance to travel on business because of the costs that must be borne in advance. Al-Hattami, Almotairy, Toraba \& Mahgoub (2019) proposed a reengineering process in college trip requests for the efficiency of trip costs deemed burdensome for university budgets, and to increase transparency between employees and management. According to Douglas and Lubbe (2006), value conflicts in corporate travel management can lead to inefficiencies in the management process. Chen, Ren and He (2017) found that companies must prioritize the trip system in an effort to increase efficiency and reduce company costs so that employees get comfort and convenience. Based on the results of the study of Al-Hattami et al. (2019), suggest that BPR processes in official trip systems use robotic automation to address delays that may occur when engaging HR processes, and to make them fast, accurate and cost-effective. Meanwhile, Lucas (2016) found that business process reengineering requires the support of an effective Information Technology (IT) system so that it can overcome insufficient budget gaps in business processes. Based on previous studies, this study concludes that process reengineering with the support of technology systems in travel management in organizations is very important to increase efficiency and reduce costs. Higher education is an organization that focuses on the field of education, so its business processes are different from other organizations in general. However, studies that focus on process reengineering in universities are still very limited. 
This study focuses on evaluating the existing process, compiling the design and implementation of a BPR online-based official trip system with a multi-unit integration approach in Telkom university as one of the best private universities in Indonesia. This study uses a resource-based approach where people, as the most important management aspect, are considered as a determining factor in the successful implementation of business process improvements. Multi-unit integration encourages institutional ideas to solve these problems by evaluating and engineering business processes so as to create better performance. This study uses a mixed-method with an embedded design approach. The quantitative method is carried out by calculating the performance of official trip procedures which includes the calculation of processing time and equipment used both before and after the BPR. Meanwhile, the qualitative method was carried out by conducting interviews and Focus Group Discussions (FGD) with key informants from related units in evaluating the implementation of the online-based official trip system in universities.

This paper consists of several sections covering the background and research phenomena in the first part. Then, the second part contains a review of the literature review related to this study. The third part is the research methodology and it explains how the stages of the research are carried out. The fourth part is findings and discussion. Finally, the research conclusions and recommendations are presented in the fifth section.

\section{Literature Review}

\subsection{Official Trip System}

Official trips are trips that must be carried out by employees at the behest of the Board of Directors/Supreme Leaders/Institutional Leaders/Unit Leaders which include trips due to assignments, training, seminars, conferences, comparative studies, work visits, and special official trips. Official trips are an incidental task carried out by a secretary (Sedarmayanti, 2018). However, currently, official trips are not only carried out by the secretary, but also include certain agencies that take care of the official trip. According to Rachmawati, Retnasari and Sunarto, (2018) an official trip is a trip given to an employee in carrying out a task for the benefit of the office and being outside the region, and given certain facilities. In addition, Sedianingsih, Mustikawati and Soetanto (2014) suggests that an official trip is a trip carried out by employees of a company that is related to the interests of official duties of the company concerned.

The results of the study by Silvana, Fajrin and Danton (2015) revealed that the Regional Office II of PT. Pos Indonesia (Persero) issued official travel warrant (In Indonesia, called SPPD). This letter is important because it is needed for documentation and recording in the official affairs of employees at PT.Pos Indonesia (Persero), both regional and central. In the process of making SPPD, most government and private agencies still carry out simple manual recording using the help of Microsoft Office, not yet using a special application for making SPPD.

In accordance with the Regulation of the Minister of Finance of the Republic of Indonesia Number 113/PMK.05/2012 concerning Domestic Service Trips for State Officials, Civil Servants, and Non-Permanent Employees, the type of domestic official trip is divided into two, namely official trip and official transfer. The meaning of official trip is an official trip across city boundaries and/or within the city from the domicile to the destination, carrying out the task, and returning to the original domicile in the country. Meanwhile, an official transfer is an official trip from the old place of domicile to the new place of domicile based on a transfer decision letter. Based on the explanation of the law, it can be explained that an Official Trip Order is a document that functions as a communication tool issued by the Commitment Officer for other parties (employees) in the context of carrying out an official trip.

In addition, official trips are also divided into Domestic Service Trips and Foreign Service Trips. Domestic Service Trip is an activity of a Foundation/Institution which must be carried out by employees at the behest of the Executive Board/leadership at the Office of the Executive Board of the Foundation/Head of the Institution and carried out at a place/location that is at least 50 (fifty) kilometres from the work area/location. Meanwhile, Foreign Service Trip is an activity of a Foundation/Institution which must be carried out by employees at the order of the Executive Board outside the territory of the Republic of Indonesia. Domestic Service Trip regulation is regulated in PMK 113/PMK.05/2012 while PDLN is regulated in PMK 164/PMK.05/2015. Domestic Service Trips are divided into General Service Trips and Special Service Trips. 
Douglas and Lubbe (2006) revealed that travel management in business organizations is the management of employee travel activities with a centralized function arrangement. According to Savitri and Amaliah (2017), the official trip system is very important because it relates to the financial statements of an institution. Therefore, official trip data must always be stored properly in the database of a government agency/organization. According to Wynstra, Axelsson and van der Valk (2006), this business trip can be classified as a business service because employees travel related to their work. Prasetyaningrum and Juanita (2018) said that a developed official trip information system can improve time efficiency in submitting detailed cost reports and also checking reports to be much more quickly.

In this study, the official trip system can be defined as a system that regulates all matters concerning official trips carried out by employees related to the interests of official duties. The official trip system is part of the business process at higher education institutions, Holma (2012) revealed that university productivity is achieved when carrying out employee official trips efficiently. Thus, the official trip system is an important part of the higher education institution's business process.

\subsection{Business Process Re-engineering (BPR)}

The keywords for BPR are "fundamental", "radical", "dramatic", "change" and "process". A business process must undergo fundamental changes to increase productivity and quality. Davenport and Short (1990) described BPR as the analysis and design of work flows and processes within and between organizations. According to Davenport (1993), BPR is a measured and structured activity to produce certain outputs for certain customers. There is also an emphasis on "how" the work is carried out in an organization. Therefore, a business process can be defined as a process that includes a specific sequence of work activities and clearly defines inputs and outputs. According to Hammer and Champy (1993), BPR is a fundamental rethinking and a radical re-design of business processes to achieve dramatic improvements in critical measures of performance, such as cost, quality, service, and speed. Table 1 below is some of the definitions of BPR from previous studies.

Various other definitions have been disclosed in previous research which states that BPR is a process of organizational change, both large and small, including business process improvement (Harrington, 1991), core process redesign (Kaplan, Murdock \& Ostroff, 1991), business process transformation (Burke \& Peppard, 1993), breakpoint business process redesign (Johansson, 1993), business process management (Lee \& Dale, 1998), redefined business scope (Venkatraman, 1994), ecology of organizational change (Earl, Sampler \& Short, 1995), and structured analysis and improvement (Zairi, 1997). From these definitions, it can be understood that the ultimate goal of reengineering process is to achieve efficiency and effectiveness by radically rethinking the existing process; whereas the goal of total quality management is to make process changes gradually by working in additional steps (O’Neill \& Sohal, 1999).

\begin{tabular}{|l|l|}
\hline \multicolumn{1}{|c|}{ Author } & \multicolumn{1}{c|}{ Definition } \\
\hline $\begin{array}{l}\text { Penrod \& Dolence } \\
(1992)\end{array}$ & $\begin{array}{l}\text { BPR is “using the power of modern information technology to radically redesign administrative } \\
\text { business processes to achieve dramatic increases in their performance." }\end{array}$ \\
\hline Talwar (1993) & $\begin{array}{l}\text { BPR is a rethinking, restructuring and streamlining of business structures, processes, work methods, } \\
\text { management systems and external relations through which the value is created and delivered. }\end{array}$ \\
\hline $\begin{array}{l}\text { Petrozzo \& Stepper } \\
(1994)\end{array}$ & $\begin{array}{l}\text { BPR is a process that involves the simultaneous redesign of processes, organizations, and supporting } \\
\text { information systems to achieve radical increases in time, cost, quality, and customer appreciation of } \\
\text { the company's products and services. }\end{array}$ \\
\hline Lowenthal (1994) & $\begin{array}{l}\text { BPR is an activity to rethink and redesign processes in operations or organizational structures that } \\
\text { aim to improve organizational performance, which focuses on the core competencies of the } \\
\text { organization. }\end{array}$ \\
\hline $\begin{array}{l}\text { Bennis \& Mische } \\
(1995)\end{array}$ & $\begin{array}{l}\text { BPR is a process of rearranging existing practices and activities and then innovatively redistributing } \\
\text { capital and human resources into a cross-functional process. }\end{array}$ \\
\hline $\begin{array}{l}\text { Elzinga, Horak, Lee } \\
\& \text { Bruner (1995) }\end{array}$ & $\begin{array}{l}\text { BPR is a structured approach to analyzing and continuously improving fundamental activities such as } \\
\text { manufacturing, marketing, communications and other key elements of a company's operations. }\end{array}$ \\
\hline
\end{tabular}




\begin{tabular}{|l|l|}
\hline \multicolumn{1}{|c|}{ Author } & \multicolumn{1}{c|}{ Definition } \\
\hline $\begin{array}{l}\text { Gunasekaran \& } \\
\text { Kobu (2002) }\end{array}$ & $\begin{array}{l}\text { BPR concerns fundamental rethinking and radical redesign of business processes to achieve } \\
\text { dramatic and continuous improvements in quality, cost, service, lead time, flexibility and innovation. }\end{array}$ \\
\hline Bhaskar (2018) & $\begin{array}{l}\text { BPR is one of the fastest growing effective management tools for industries that are in dire need of } \\
\text { change and improvement, especially when the required scale of change is large. }\end{array}$ \\
\hline
\end{tabular}

Table 1. Definition of BPR

The purpose of BPR according to Hammer and Champy (1993) is to increase customer focus, to speed up the cycle, and to increase process efficiency (Wisayani, Kertahadi \& Riyadi, 2014). According to Bennis and Mische (1995), the commonly used BPR stages include:
a) Understand the process that is taking place
b) Identify weak points in existing processes
c) Investigate alternative redesigns
d) Look for IT usage opportunities.
e) Model new, efficient processes.

Kenneth, Enefaa and Deedam-Okuchaba (2018) stated that BPR tries to take a big picture of an organization's processes with the help of certain principles, and decide whether the processes require changes to make them more precise and relevant for organizational goals. Sungau, Ndunguru and Kimeme (2013) said that organizations adopt BPR techniques in order to improve business processes so that organizational performance is better; including reducing organizational costs, improving quality and customer service so as to provide customer satisfaction, and strengthening market competition among organizational services. Therefore, re-engineering should not only be about automating processes that already exist in the organization, but also how to create new processes. Based on previous research, this study defines BPR as the process of creating added value in an organization or company by utilizing IT to improve its operational processes.

\subsection{Process Reengineering Framework}

Davenport and Short (1990) proposes a BPR framework with a five-step approach to redesigning business processes by explaining the role of information technology. Figure 1 below represents the redesign process proposed by Davenport and Short (1990).

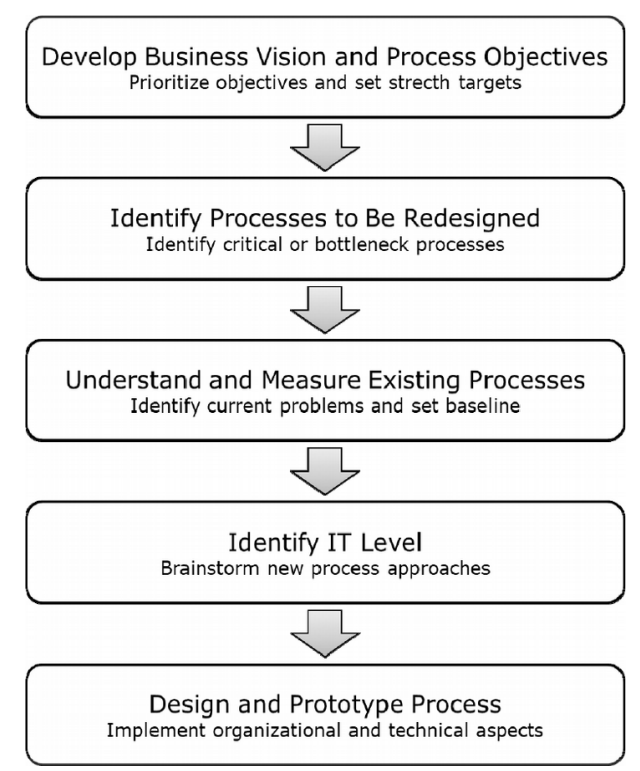

Figure 1. Redesign Process (Davenport \& Short, 1990) 
Previous research proposing a BPR framework in higher education institutions is limited (Penrod \& Dolence, 1992; Allen \& Fifield, 1999; Adenso-Díaz \& Canteli, 2001; Educause, 2005; Okunoye, Frolick, \& Crable, 2006, 2008; Abdous, 2011). Thus, this study focuses on analyzing the implementation of BPR in higher education institutions using the framework proposed by the previous studies. The framework of this study is based on a retrospective analysis of the experiences of medium-sized universities in reengineering internal processes, such as academic staff development management systems (Abdous, 2005), implementation of distance learning exam scheduling and distribution (Abdous \& He, 2008), BPR framework on universities (Abdous, 2011), a case study on the implementation of the online SPPD system development in higher education, and various literatures related to BPR. This study focuses on educational institutions in building an online SPPD system as a form of excellence in creating an efficient and effective system. The study divides four sequential and non-linear phases of BPR based on the framework from Abdous (2011) which consists of:

1. Initiation. This phase aims to identify and understand the objectives, rationale, and objectives of the review process. This phase requires the active participation of all stakeholders to document and understand the environmental dynamics and risks associated with the proposed reengineering process (Hengst \& de Vreede, 2004).

2. Analysis. This second phase involves an in-depth analysis of process tasks and procedures by analyzing tasks, reviewing risks and assumptions, and by identifying potential causes of resistance and inertia. With the documentation obtained during the first stage, the results from this analysis stage are used to create a process flow chart. The visual presentation of the existing process dependencies and interdependencies is not only important for mapping the core tasks and procedures of the process, but also the basis for the reengineering process itself.

3. Re-engineering. This third phase is intended to design the features and functions of the reengineering process, and includes active participation and feedback from all personnels and appropriate users. As the process was redesigned, the flowchart outlined in the second stage was updated to include clarification of the main measurement variables. In this phase, information technology is used as a supporting tool and facilitator.

4. Implementation and evaluation. The implementation and evaluation phase is intended as the first step to prototyping a re-engineered process, thereby addressing user and stakeholder issues and concerns. In the second step, the re-engineered process is fully implemented and monitored to ensure a successful operation. A summative evaluation is conducted, and achievements and results are reported.

As illustrated in the framework of Abdous (2011) below, it can be seen that BPR implementation is not only a change in process but it needs to be supported by a basic understanding of Organizational Culture, Leadership and Information Technology support. The discussion in this study emphasizes things that are technical/hard skills in the form of information technology support (digitization and digitalization). Discussion of soft skills support in the form of work methods used to support problem solutions will be discussed in separate essay.

This study focuses on BPR in the official trip system in universities, where the evaluation process is carried out based on the analysis of the speed and the ease of the process (Hammer \& Champy, 1993) and process acceleration (Wisayani et al., 2014); Cost (Hammer \& Champy, 1993) and Efficiency (Wisayani et al., 2014) from a financial aspect; Quality (Hammer \& Champy, 1993) which includes work quality, communication quality, and system quality; Services (Hammer \& Champy, 1993) related to how HR can provide services to users with ease in the SPPD submission process; and, customer focus (Wisayani et al., 2014; Taouab \& Issor, 2019) by identifying the needs and expectations of users and building good relationships with users to increase user satisfaction. 


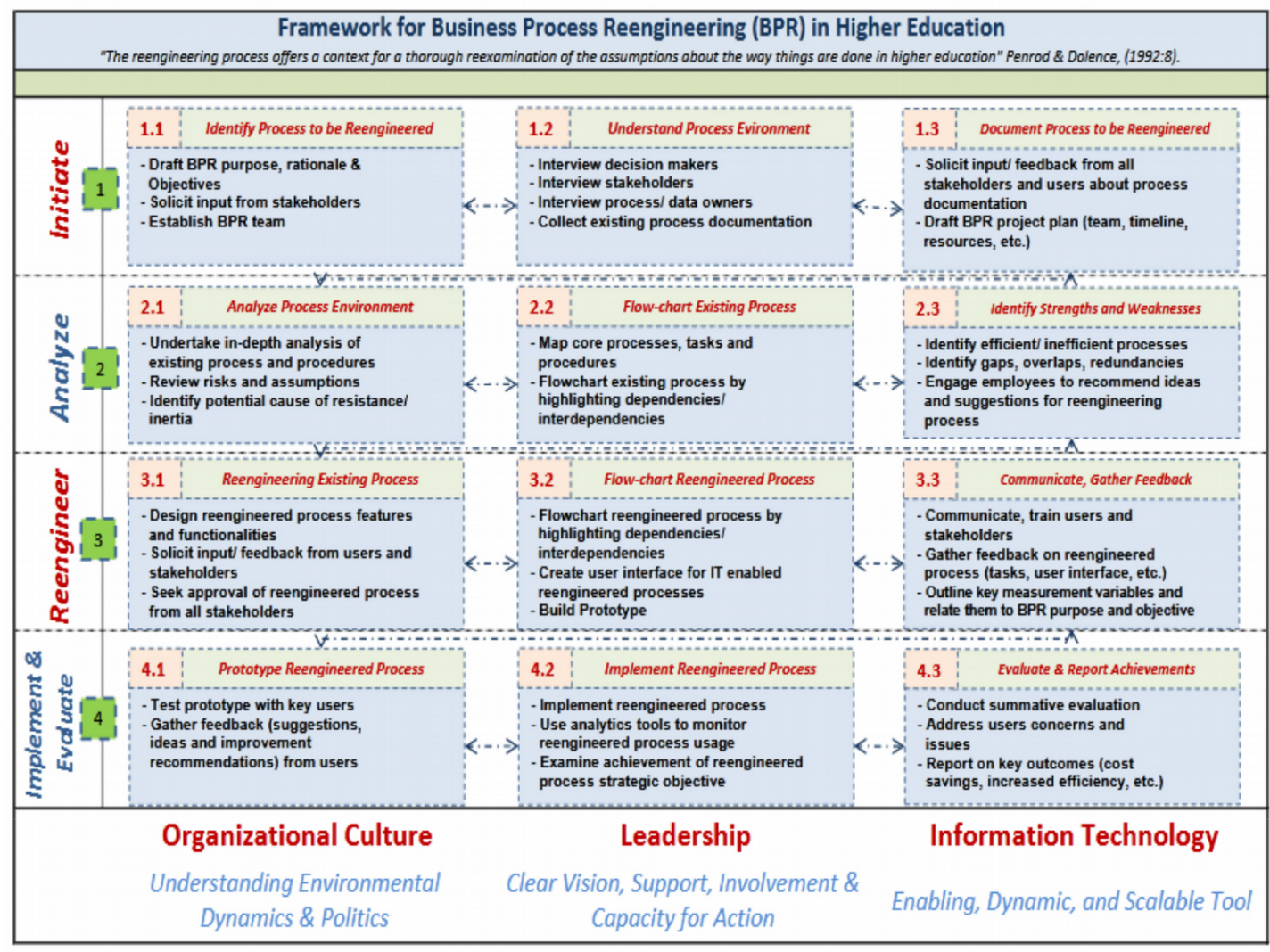

Figure 2. Process Reengineering Framework (Abdous, 2011)

\section{Research Methodology}

\subsection{Research Design}

This study uses a mixed method approach with an embedded design approach. The quantitative method is carried out by calculating the performance of official trip procedures before and after the BPR. Meanwhile, qualitative methods are carried out by building and designing a framework and system for online-based official trip in tertiary institutions. The choice of a qualitative research model really depends on the perspective used by the researcher and the research objectives (Creswell, 2007). This study used a case study approach, where the researcher conducts an in-depth exploration of a program, event, activity, process, and individual (Creswell, 2003). This study focuses on designing and implementing BPR on the workflow of official trip procedures through a multi-unit team. The figure 3 below shows the framework for this research based on Miles and Huberman (1984).

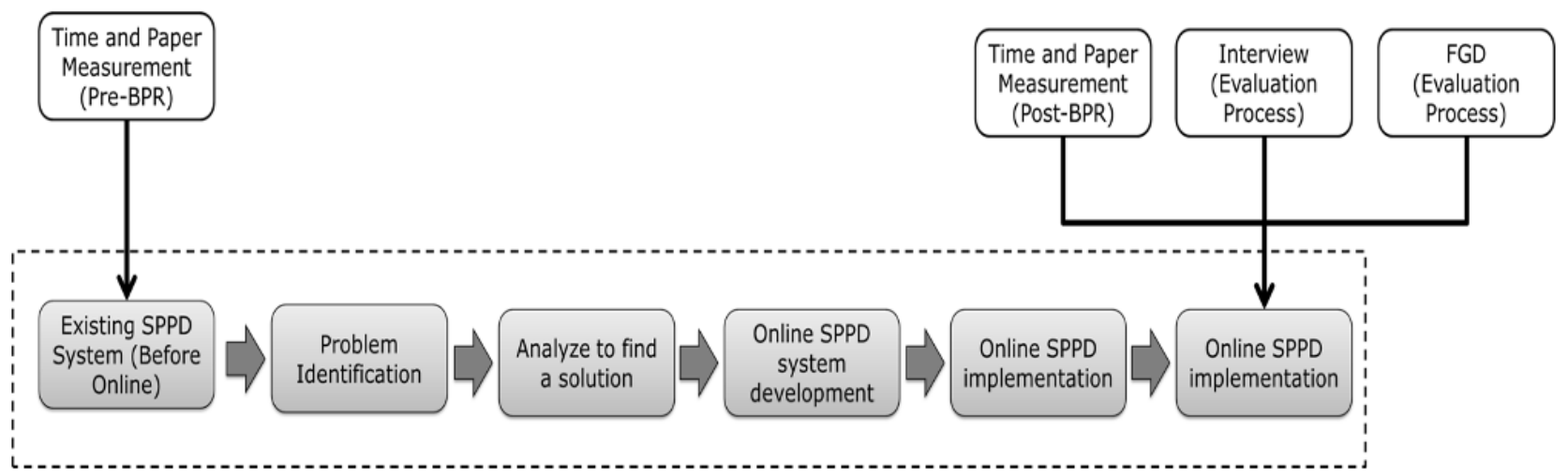

Figure 3. Research Stages 


\subsection{Sample}

This research is focused on one of the higher education institutions in Bandung, West Java. A case study of Telkom University as one of the best private universities in Indonesia is presented in this study. Telkom University was founded in 2013 which is a combination of 4 higher education institutions under the Telkom Education Foundation (Telkom Institute of Technology, Telkom Institute of Management, Telkom Polytechnic, and Telkom Indonesia College of Art and Design). Telkom University has been the No.1 private university for 2 consecutive years, since 2019 and 2020. Telkom University has succeeded in being among the world's best universities based on rankings from Times Higher Education (THE), World University Rankings (WUR), QS World University Rankings Regional ASIA, and Webometrics. In addition, Telkom University also managed to get 4 Stars Overall in the QS Stars assessment (Telkom University, 2021).

From the results of a preliminary study at Telkom University (Tel-U), in the form of input from the staff to the Dean level, it was found that the slow process of official trip is a problem that occurs in this institution. The duration of the process can take a very long time, even in certain cases funds can be disbursed 2-3 weeks after employees return from official trips. Hence, this problem must be resolved immediately because it has been going on for a long time since the establishment of Telkom University in 2013.

The quantitative method of this study uses a business process management formula by measuring process performance using time and cost indicators (Romero \& Abelló, 2013). Time and cost calculations are based on the official trip process carried out at Telkom University, from the submission process until the funds are received by employees.

Meanwhile, the main data sources of qualitative research are words and actions (Silverman, 2019). Therefore, the main instrument in this study is the researcher who directly conducted interviews which are expected to be able to analyze the qualitative data obtained from informants. Multi units (squad) and users participate as samples. The sample units are selected based on their involvement in the formulation of the official trip system and system users. The informants are key actors who have a role in the success of the online official trip system program. A total of 11 people were involved in the interview process as informants of this study. All informants responded well to questions and understood the problems that occurred. The table 2 below shows the profile of the informants in this study.

\begin{tabular}{|c|c|l|l|}
\hline No. & Code & \multicolumn{1}{|c|}{ Informant Position } & \multicolumn{1}{c|}{ Role } \\
\hline 1 & A1 & Vice Chancelor & Key actor \\
\hline 2 & C1 & Head of Finance & Key actor \\
\hline 3 & D1 & Head of HR services & Key actor \\
\hline 4 & B1 & Deputy Dean of the Faculty & User \\
\hline 5 & D2 & Head of Faculty of HR Affairs 1 & User \\
\hline 6 & D3 & Head of Faculty of HR Affairs 2 & User \\
\hline 7 & E1 & Career and Endowment Staff 1 & User \\
\hline 8 & E2 & Career and Endowment Staff 2 & User \\
\hline 9 & E3 & Faculty Staff (detail officer) & User \\
\hline 10 & C2 & Head of IT Research and Budget Section & Developer \\
\hline 11 & D4 & Head of User Services & Developer \\
\hline
\end{tabular}

Table 2. Informant Profiles

\subsection{Data Collection}

Quantitative data are obtained based on observations and calculation estimates from the process. Meanwhile, qualitative research is based on social context; thus, data is collected from field observations, in-depth interviews 
and FGD with key people. Semi-structured interviews were conducted face-to-face with each respondent. The interview lasted about 1-2 hours for each informant. Interviews were conducted in Indonesian. Furthermore, the FGD process invites all informants to discuss together about the evaluation of the system that has been implemented. Based on the informants' permission, we used notes and recording devices to document the results of the interviews. The results of the interviews and FGDs were then transcribed and verified by the informants. This information from these informants allows us to double-check the data and improve consistency and reliability. In addition, to ensure data validity/data credibility, this study uses triangulation of sources and techniques. Source triangulation is done by comparing information from one respondent with other respondents using the same data collection techniques. Meanwhile, technical triangulation is carried out by comparing data using several techniques, such as observation, in-depth interviews, and documentation.

\subsection{Data Analysis}

Quantitative data calculation is done manually by calculating the estimated processing time and costs before and after the BPR. Before the BPR process, we calculate lead times based on all processes from submissions to funds received by employees. Meanwhile, the cost is calculated from the paper (sheet) issued. After the BPR process, to calculate the process efficiency the following formula is used:

$$
\begin{aligned}
& \text { Process Efficiency }(\%)=\text { Value-added Time } / \text { Lead Time x } 100 \\
& \text { Value-added time }=\text { Lead time }-(\underbrace{\text { Wait time }+ \text { Block time })}_{\text {Non-value adding }}
\end{aligned}
$$

\section{Description:}

Lead time: The entire cycle time of the card (from "Business requirement" to "Done"

Value-added time: the time spends in activity columns such as "Development" and "Verification".

Non-value adding: the time spent in queue columns like "waiting for review" or blocked.

Meanwhile, qualitative research uses data analysis techniques proposed by Miles and Huberman (1984) based on the book written by Punch and Oancea (2014), where qualitative data analysis is carried out interactively and continuously until completion, which includes data reduction, data display, and conclusion/verification. Figure 4 below shows the stages of Miles and Huberman (1984)'s qualitative analysis.

Data Reduction is carried out throughout the analysis process. The objective is to reduce the number of data without removing a significant number of information. In the early stage of data processing, data reduction is performed in editing, restricting and summarizing data. In the middle stage, data reduction is performed in research activities such as coding, pattern finding and grouping. Finally, in the last stage, data reduction is performed in describing and summarizing data. In this research, data reduction is carried out in qualitative data processing, especially in interview results. Thick description is required to validate data, but it wasn't always relevant with the research.

Data Display is a process of organizing, summarizing and sorting acquired data since qualitative data is generally scattered in a large volume. Data display can be made in a form of schemes, graphics, diagrams, tables, and any other way that helps with the analysis process. The objective is to ease the process of data accessing.

Drawing/Verifying Conclusion is the reason why Data Reduction \& Data Display is carried out, which is to help concluding the result of the research. 


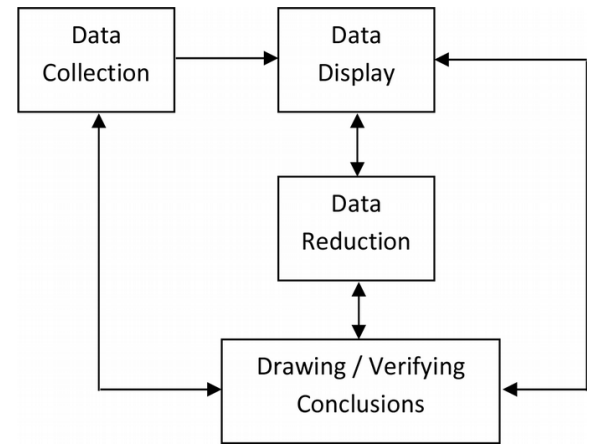

Figure 4. Relationship Between Data Components

The data validation used source triangulation technique. Source triangulation is done to confirm information from several sources or research informants. Source triangulation is done by comparing data from several sources or informants. This research is supported by reference material as a support to prove and test the credibility of the data that the researcher has found. This study seeks to build an online-based official trip system framework by understanding the existing conditions in the field regarding the problems that occur. Data analysis is carried out to provide a better understanding of the cases studied by describing the findings from the data collected. Evaluation studies are used to identify the effectiveness and efficiency of implementing the system being built. Quotations from interviews are used as further evidence (Wolcott, 2008). The data interpretation is illustrated in the model implications of the official trip system in higher education. The framework is built based on field investigations, interviews, and system analysis. The steps and sequence of official trip system procedures are described to provide further understanding.

\section{Research Results}

\subsection{Case study}

\subsubsection{Initialization}

The process of official trip has become a chronic problem for Telkom University employees, and this is an assessment of the performance of the process owner, especially the financial function. Based on this, at the end of September 2019, Vice Rector II decided to carry out a process improvement effort with the main objective of accelerating the process time starting with forming a multi-unit team. Through intense and persistence efforts by conducting various discussions, coordination and meetings with key staff in charge, starting from the operational level up to the level of the related structural officials, to find out the problem in detail in the SPPD process which was currently running. Based on the preliminary results, an initial description of the SPPD process at Telkom University is obtained which is shown in the Figure 5.

All : 11,32 wd to 8,9 wd

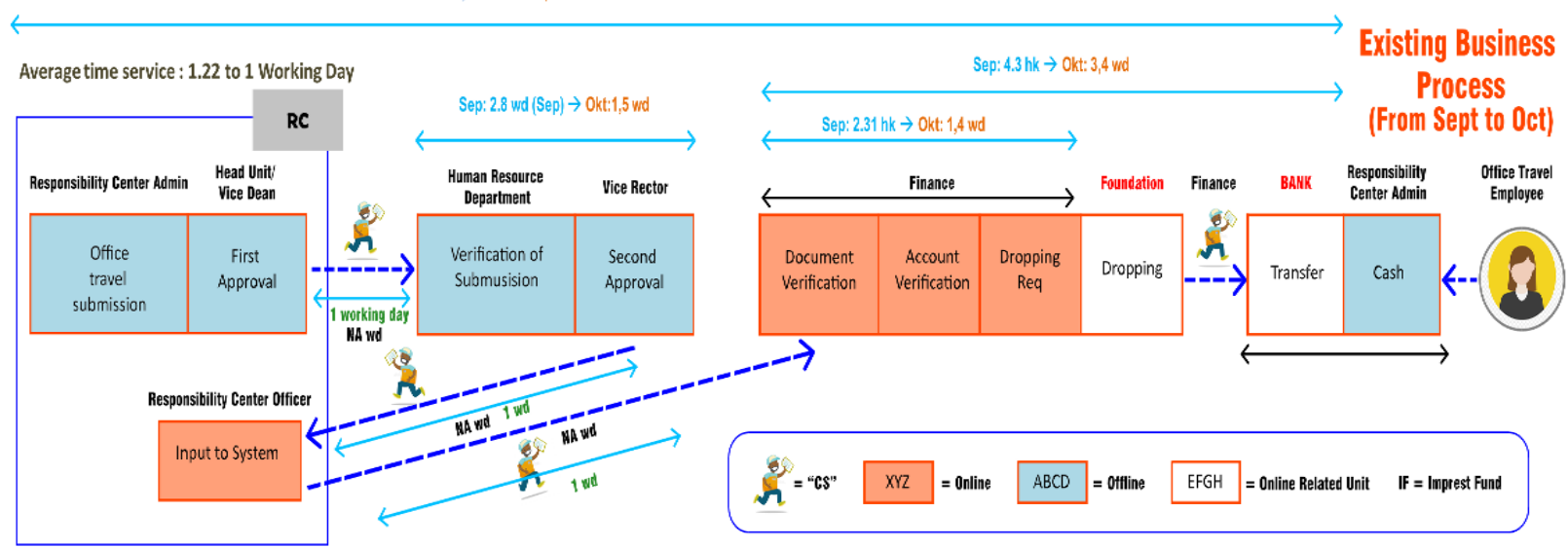

Notes: RC: Responsibility Center; CS: Cleaning Service; NA wd: Not Acknowledged (units) working days.

Figure 5. Telkom University SPPD Process Flow (Before Online) 
The process starts with the application for official trip from the unit, the process is carried out using paper and manually submitted to the Unit Administration officer for approval from the Head Dean/Vice Dean of the Faculty as the first Approvals (in picture RC). The delivery of files in the Tel-U area is carried out by the Cleaning Service (CS) of each unit to be sent to the HR Unit located in the Rectorate Building. The delivery of this file is done manually by CSs who have the main task of maintaining the cleanliness of the unit which is their responsibility. The delivery process time by CS is not recorded in a structured manner so there is no measurement result yet and in the picture above is written as NA wd (not available). Furthermore, "all" application documents are entered into the HR Unit to be verified based on the number of days, type of official trip, tariff, etc. manually by the officer which is then submitted to the Vice Rector II, in charge of HR, Finance, Logistics \& Asset, and Information Technology Center, to get approval. The number of files that need to be verified by the officers and HR officers must be signed entirely by Vice Rector II. After the file is signed by the Vice Rector II, it is then brought by CS from the Rectorate building back to their respective units manually to be input by the administrative officer to the Tel-U Financial Information System (Called, Simkug system). After inputting, the document files are brought again by CS to the Rectorate building to be submitted to the Finance Unit for the financial document verification process and account checking of the official trip costs concerned. Furthermore, the finance unit will issue a Payment Order. The final process is that document files are sent by expedition/manually to the Bank as the basis for the Imprest Fund (IF) officers in each unit to disburse funds. This IF officer will then hand over PD funds in cash to the employee concerned. If a file error occurs, the process returns to the unit, which may take longer.

To determine the performance of the initial process, processing time measurements have been made based on Figure 5 above, starting from submissions from the Unit to processing payments through the Bank.

\begin{tabular}{|c|l|c|}
\hline No & \multicolumn{1}{|c|}{ Unit } & Day(s) \\
\hline 1 & Faculty of Economics and Business & 1 \\
\hline 2 & Faculty of Industrial Engineering & 1 \\
\hline 3 & Faculty of Electrical Engineering & 1 \\
\hline 4 & Faculty of Creative Industries & 1 \\
\hline 5 & Faculty of Applied Sciences & 1 \\
\hline 6 & Faculty of Business Communication & 1 \\
\hline 7 & Library & 3 \\
\hline 8 & Secretary & 1 \\
\hline 9 & IO & 1 \\
\hline & Average & 1.22 \\
\hline
\end{tabular}

Table 3. The Average Estimated Process Time of SPPD from Each Unit

Table 3 above is the result of data analysis from interview and observation carried out using Miles and Huberman's method. Below is the explanation of the result shown in Table 3.

1. The average days of the duration of the submission process for all related units is 1.22 days.

2. Each CS movement is assumed to have a duration of $1 \mathrm{wd}$. From Figure 3, it can be seen that there are 3 CS movements that are not included in the surrounding process stages so that in total there are $3 \mathrm{wd}$.

3. Processes in HR and Vice Rector II units: 2.8 wd. (Source: average manual process record data from September 2020)

4. Processes at Kug and Bank units: 4.3 wd. (Source: average data on Simkug System and Bank process records from September 2020)

5. Based on points $1-4$ above, the total leadtime of the initial process is $1.22+3+2.8+4,3=11.32 \mathrm{wd}$. 
6. Apart from processing time, prior to implementation of the BPR, the use of paper for each application for official trip is 5 (five) sheets, assuming there are no print errors.

\subsubsection{Analyse}

Based on intensive and regular FGDs, the results of the analysis suggest that the processes that have the potential to be engineered are:

\subsubsection{The process of delivering documents by $C S$}

The existing process can reduce the main task performance of CS officers in their work units as cleaners and the delivery process which may not be monitored. So that the digitization process is needed. However, there are other factors, where this process cannot be fully digitized because the foundation's rules regarding audit interests still require printout documents so that there is still manual movement for document delivery.

\subsubsection{Manual verification of SPPD cost calculation}

This process allows for human error and the existence of subjective factors for verification officers, so it is necessary to digitalize the calculation of official trip costs where rates and formulas can be entered into system parameters, meanwhile, the days and types of official trips become variable data which are input directly by the officers in each unit. The verification function is carried out by the online official trip application system. HR unit officers who have been conducting verification no longer need to carry out this verification process except in certain conditions when necessary. The HR unit in this case remains responsible for the official trip process including the accuracy of rates and formulas used by the application.

\subsubsection{The bighly centralized approval process by Vice Rector II in the Rectorate (except for Vice Rector II approval by the Rector)}

This process is very inefficient, time consuming as it uses a paper/printed mechanism for approval with signatures on all documents from the submitting units. Changes in the approval process whereby the approval process is cascading or decentralized according to the structure of employees. This can be supported by IT support/online SPPD application. The possibility of resistance from structural officials who increase their duties for the approval process is mitigated by the benefits that will be obtained by all parties, especially in terms of time, online systems (no longer paper based) and the ability of management to monitor their staff on official trips. Analysis of the risk of increasing the realization of the burden of PD has also been studied where it is concluded that the risk is relatively low because the historical proportion of realization is below $2 \%$ of the total cost. Another value of decentralization/cascading shows that the rector has trust in the independence of the unit in managing finances so that solidity is expected to increase.

\subsubsection{The process of disbursing funds to employees through the Imprest Fund Unit officer}

The process through IF officers is still needed if there is a bailout from the unit for employees. However, efforts were made to make the official trip process faster so that the disbursement of funds could be given directly to employees. As an alternative to the existing process, the Finance unit can directly ask the bank to immediately transfer to employees and expand cooperation with LinkAja partners to save PD costs for employees in their accounts.

\subsubsection{Reengineer}

Changes in engineered business processes did not occur at the operational level only, but at each stage it was reported and discussed at the team level, testing to users and subsequently at the leadership level of all universities. This is done to accommodate input and direction for the business process designed by the team. From the series of processes, it was also concluded that the process design will be equipped with features for monitoring the progress of submissions and reporting on the processing time of each unit/function. After collecting and analyzing the obtained data using Miles and Huberman's method, resumes from the analysis and engineering of the official trip process are tabulated in Table 4 
Based on the analysis and engineering stages above, the radical changes made are embodied in the design of a new business process as shown in Figure 6.

\begin{tabular}{|c|c|c|c|c|c|}
\hline No & Process & Initial & To Become & $\begin{array}{l}\text { Type of } \\
\text { Process } \\
\text { Change }\end{array}$ & Value Added \\
\hline 1 & $\begin{array}{l}\text { Application } \\
\text { for official trip } \\
\text { from the Unit }\end{array}$ & $\begin{array}{l}\text { Paper documents } \\
\text { delivered/expeditio } \\
\mathrm{n} \text { by employees }\end{array}$ & $\begin{array}{l}\text { Online entry in theOnline } \\
\text { SPPD Application ver.1 }\end{array}$ & $\begin{array}{l}\text { Process removal } \\
\text { (digitization \& } \\
\text { digitalization; } \\
\text { eliminate } \\
\text { manual } \\
\text { processes) }\end{array}$ & $\begin{array}{l}\text {-Faster } \\
\text {-Cleaning Service } \\
\text { (CS) can focus } \\
\text { more on the main } \\
\text { task }\end{array}$ \\
\hline 2 & $\begin{array}{l}\text { SPPD cost } \\
\text { calculation } \\
\text { verification }\end{array}$ & $\begin{array}{l}\text { Performed } \\
\text { manually by } \\
\text { employees of the } \\
\text { HR unit. } \\
\text { Possible human } \\
\text { error and } \\
\text { subjective }\end{array}$ & $\begin{array}{l}\text { Rates/formulas entered in the } \\
\text { Online SPPD application } \\
\text { ver.1 }\end{array}$ & $\begin{array}{l}\text { Process removal } \\
\text { (digitalization; } \\
\text { eliminate } \\
\text { manual } \\
\text { processes) }\end{array}$ & $\begin{array}{l}\text {-Faster } \\
\text {-No buman factor } \\
\text { (HR Unit } \\
\text { employees no } \\
\text { longer perform } \\
\text { manual verification; } \\
\text { can be optimized } \\
\text { for other processes) } \\
\text {-Fairness, Objective }\end{array}$ \\
\hline 3 & PD approval & $\begin{array}{l}\text { Very centered on } \\
\text { Vicer Rector II }\end{array}$ & $\begin{array}{l}\text { Decentralization/Cascading } \\
\text { to superior } 1 \text { and superior } 2 \text {; } \\
\text { the entry approval process in } \\
\text { the Online SPPD ver. } 1 \\
\text { Application }\end{array}$ & $\begin{array}{l}\text { Process } \\
\text { improvement } \\
\text { (digitalization) }\end{array}$ & -Faster \\
\hline 4 & $\begin{array}{l}\text { Disbursement } \\
\text { of funds to } \\
\text { employees }\end{array}$ & $\begin{array}{l}\text { Through Imprest } \\
\text { Fund officers }\end{array}$ & $\begin{array}{l}\text { Additional alternative } \\
\text { processes: 1) initial 2) direct } \\
\text { transfer from the bank to the } \\
\text { employee 3) from the bank to } \\
\text { the employee LinkAja } \\
\text { Supported by the Financial } \\
\text { Application System and } \\
\text { existing collaborations with } \\
\text { Partners (Bank, LinkAja) }\end{array}$ & $\begin{array}{l}\text { Process } \\
\text { additional } \\
\text { (digitalization; } \\
\text { alternative } \\
\text { processes) }\end{array}$ & $\begin{array}{l}\text {-Faster } \\
\text {-Multiple ways }\end{array}$ \\
\hline
\end{tabular}

Table 4. Resume of Official Trip Process Analysis and Engineering Results

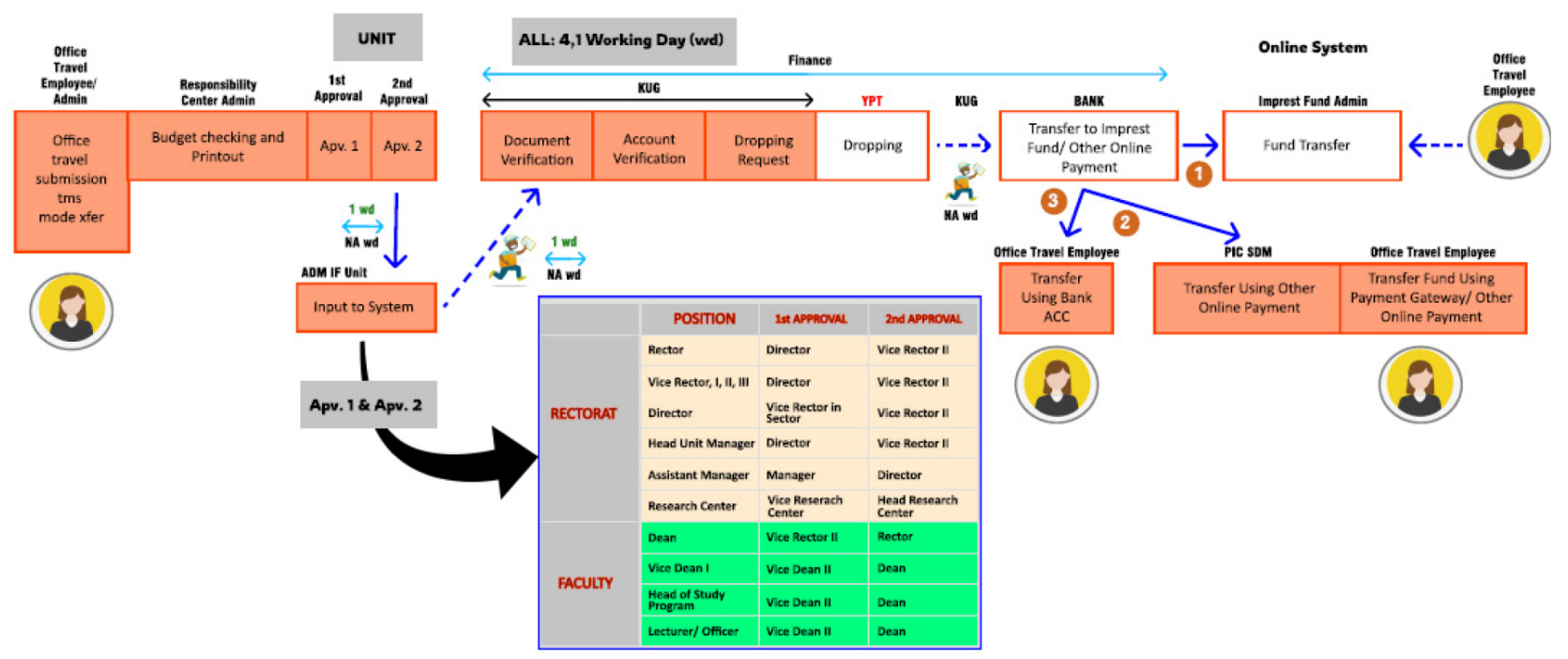

Figure 6. Process Flow of Business Process Engineering Results Version 1 


\subsubsection{Implementation and Evaluation}

\subsubsection{Implementation}

Based on the process flow designed by the team and submitted to the Tel-U application development unit, the Online SPPD application version 1, which was named PeDi ver.1, was developed. In order to manage risk, application implementation is carried out in stages through piloting stages in several units and faculties. After the pilot is considered successful, the deployment continues to all units but still uses a parallel run system. After the new system has run similarly to the old system, then the old system is cut off from operation and the new system runs completely. In each stage of the implementation iteration, the evaluation process including input from the function/unit concerned as well as reporting to the leadership level is carried out according to the level of authority to obtain a decision. Based on the design and development of the application system by the TelU information system unit as well as the implementation stages carried out by the multi-unit team with the support of the leaders and all Tel-U Units, since January 2020 the Online SPPD version 1 system has been implemented with a process view in Figure 7 below.

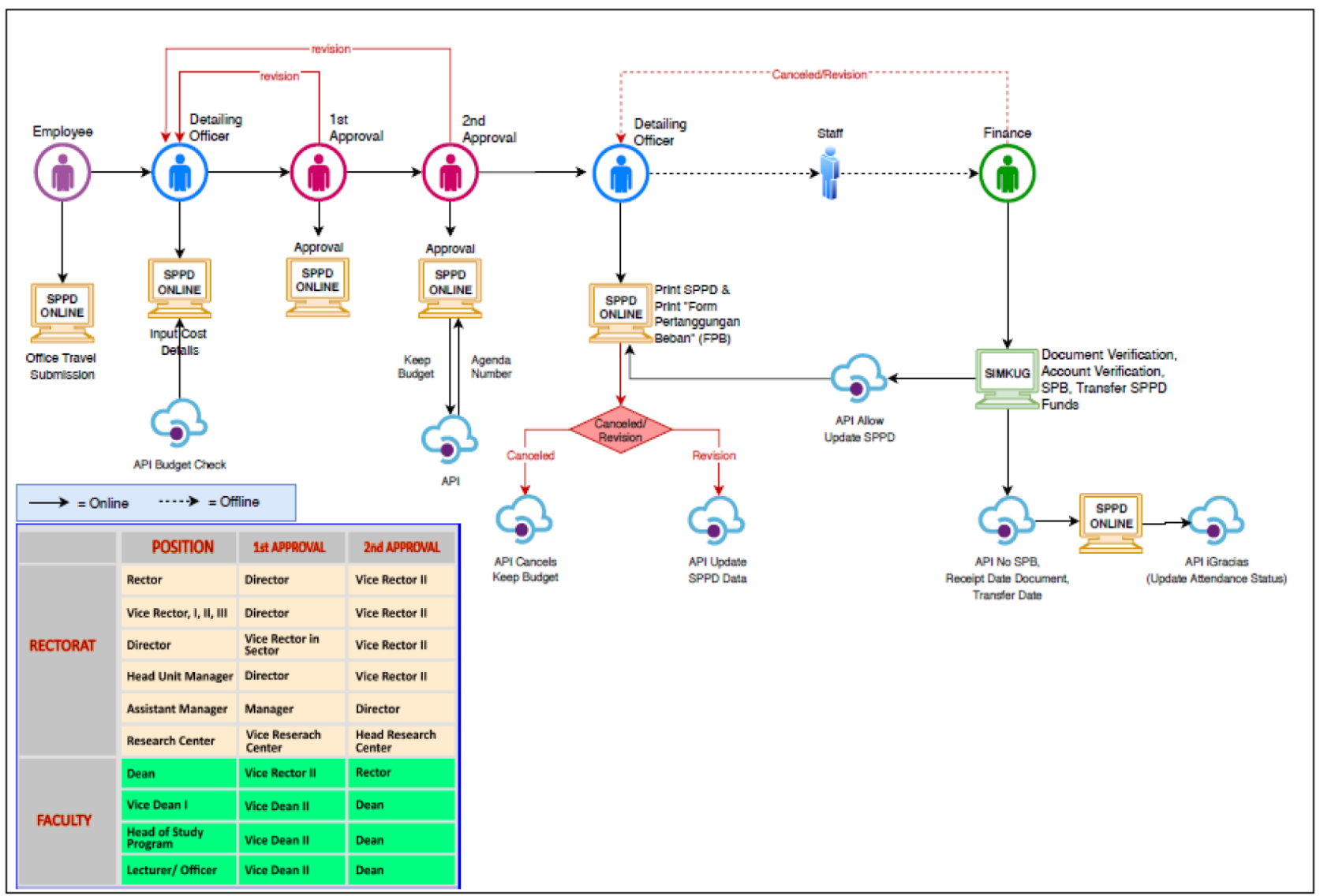

Figure 7. Online SPPD Application Business Process Version 1 designed by the Directorate of Information Technology Center, Telkom University

\subsubsection{Evaluation}

We measure the process efficiency for evaluation as follows:

Non-value adding $=$ Wait Time + Block Time

$$
\begin{aligned}
= & (\text { Verification }+ \text { Approval })+(\text { Application Submission }+ \text { CS } \\
& \text { Movement })=(2.2+1.8)+(0.22+3)=7.22
\end{aligned}
$$

Value-added time $=11.32-7.22=4.1$ 
Based on the measurement results of the implementation of process performance, the BPR has succeeded in reducing the total processing time (from submitting the unit to the bank) to $4.1 \mathrm{wd}$. This figure is very efficient considering the previous process was $11.32 \mathrm{wd}$. Apart from processing time, the use of paper for each application for official trip is reduced to 2 sheets from the previous 5 sheets, assuming there are no misprints. Saving paper means saving costs as well as reducing paper waste which supports the environment. Measurement of the online SPPD system performance is carried out to determine the efficiency of the BPR using Miles and Huberman method.

Based on the measurement results as shown in Table 5 above, the impact of BPR adoption for cost and speed variables shows positive results where the processing time is $64 \%$ more efficient, while paper use/paper costs or paper waste reduction is $60 \%$ more efficient. In terms of paper, these quantitative results can be understood and expanded as an efficiency of direct costs that can be saved from paper costs and also have a positive impact on environmental programs in the form of reducing paper waste (waste management) with the existence of BPRs by digitalizing the SPPD process from manual to online. Then, the cost efficiency seen from the use of paper is 2.5 times better and the time efficiency is 2.8 times better or faster than manual SPPD. Apart from processing time and paper usage, another positive quantitative result is the optimization of $1 \mathrm{HR}$ Unit employee who no longer verifies the calculation of official trip costs and 2 CS people who can more optimally focus on their main work.

Furthermore, the evaluation process is obtained from interviews conducted after the online system version 1 runs in full. Following are the results of qualitative data processing using data analysis by Miles and Huberman and after going through the triangulation process.

\begin{tabular}{|l|c|c|c|c|}
\hline \multicolumn{1}{|c|}{ Description } & Before BPR & After BPR & Better (times fold) & Efficiency (\%) \\
\hline Time Efficiency (Days), (\%) & $11.32 \mathrm{wd}$ & $4.1 \mathrm{wd}$ & 2.8 & $64 \%$ \\
\hline Cost Efficiency (Sheet), (\%) & 5 Sheets & 2 Sheets & 2.5 & $60 \%$ \\
\hline
\end{tabular}

Table 5. Evaluation of BPR Results Performance Measurement

Table 6 shows the results of data clustering process by collecting data through interviews taken from key role actors who have verification results from evaluations based on BPR variables as follows:

1. Cost (Hammer \& Champy, 1993) and Efficiency (Wisayani et al., 2014); With the online SPPD, universities can reduce operating costs by up to $60 \%$, thereby increasing work efficiency and costs that previously appeared can be transferred to other costs.

2. Quality (Hammer \& Champy, 1993); There is still a Simkug system that needs to be integrated with this online SPPD so that it can improve work quality, communication quality, and system quality.

3. Speed (Hammer \& Champy, 1993) and process acceleration (Wisayani et al., 2014); Online SPPD provides convenience and speeds up the process so that it is up to $50 \%$ more effective than offline processes. Improve the security of information access, ease the document management process, can be traced in real time.

4. Service (Hammer \& Champy, 1993); the service referred to in this online SPPD case is about how the HR online SPPD system can provide services to users with the ease and speed of the SPPD submission process. Based on the results of verification in improving services to users, online SPPD has provided a transparent process, progress can be accessed real time, and there is no need for a manual sign that takes time which can reduce service to users.

5. Customer focus (Wisayani et al., 2014); Customers in this online SPPD case study are system users, so that FGDs are conducted with users to participate in evaluating and providing suggestions for improving the online SPPD system. The online SPPD system is made transparent and user friendly so that it helps superiors to know the progress of the users and provides benefits to users or universities in solving 
problems that may occur in the SPPD application process. Focus on customers is to identify the needs and expectations of users and build good relationships with users to increase user satisfaction.

\begin{tabular}{|c|c|c|c|c|}
\hline BPR Variable & A1 & $\mathrm{C} 1$ & D1 & Conclusion \\
\hline $\begin{array}{l}\text { Speed (Hammer \& } \\
\text { Champy, 1993) } \\
\text { accelerates the } \\
\text { process (Wisayani et } \\
\text { al., 2014) }\end{array}$ & $\begin{array}{l}\text { Time effectiveness } \\
\text { is } 50 \% \text { faster than } \\
\text { offline }\end{array}$ & $\begin{array}{l}\text { Save more time, improve } \\
\text { security of access to } \\
\text { information and } \\
\text { documents, can carry out } \\
\text { various collaborations in the } \\
\text { digitization process such as } \\
\text { users can create, modify, } \\
\text { manage documents more } \\
\text { easily, easily send and } \\
\text { distribute files/documents. }\end{array}$ & $\begin{array}{l}\text { Digitization, one of } \\
\text { which is online SPPD, } \\
\text { is very useful, a very } \\
\text { significant change } \\
\text { from manual to online, } \\
\text { the process is more } \\
\text { integrated, faster, can } \\
\text { be measured and seen } \\
\text { when there are } \\
\text { obstacles, easier to } \\
\text { trace, all parties are } \\
\text { involved and } \\
\text { responsible for the } \\
\text { ongoing process. }\end{array}$ & $\begin{array}{l}\text { Online SPPD provides } \\
\text { convenience and } \\
\text { speeds up the process } \\
\text { so that it is up to } 50 \% \\
\text { more effective than } \\
\text { offline processes. } \\
\text { Increase the security } \\
\text { of information access, } \\
\text { ease the document } \\
\text { management process, } \\
\text { can be traced in real } \\
\text { time. }\end{array}$ \\
\hline $\begin{array}{l}\text { Cost (Hammer \& } \\
\text { Champy, 1993) } \\
\text { Efficiency (Wisayani } \\
\text { et al., 2014) }\end{array}$ & $\begin{array}{l}\text { With the online } \\
\text { SPPD, operational } \\
\text { costs such as paper } \\
\text { that are usually used } \\
\text { are reduced so that } \\
\text { operational costs } \\
\text { can be reduced by } \\
\text { up to } 60 \% \text {. }\end{array}$ & $\begin{array}{l}\text { Manual processes that are } \\
\text { replaced by automation } \\
\text { reduce human resource } \\
\text { costs so that unnecessary } \\
\text { costs can be transferred to } \\
\text { other sectors. }\end{array}$ & $\begin{array}{l}\text { The digitization of the } \\
\text { online SPPD process } \\
\text { simplifies, streamlines } \\
\text { and improves work } \\
\text { efficiency. }\end{array}$ & $\begin{array}{l}\text { With the online SPPD, } \\
\text { universities can reduce } \\
\text { operating costs by up } \\
\text { to } 60 \% \text { so as to } \\
\text { increase work } \\
\text { efficiency and costs } \\
\text { that previously } \\
\text { appeared can be } \\
\text { transferred to other } \\
\text { costs. }\end{array}$ \\
\hline $\begin{array}{l}\text { Quality (Hammer \& } \\
\text { Champy, 1993) }\end{array}$ & $\begin{array}{l}\text { There is a need to } \\
\text { improve the quality } \\
\text { of the system so } \\
\text { that it can be } \\
\text { integrated with a } \\
\text { foundation system } \\
\text { that is still not } \\
\text { connected to a } \\
\text { modular online } \\
\text { SPPD system. }\end{array}$ & $\begin{array}{l}\text { Reducing operational costs, } \\
\text { speeding up work processes, } \\
\text { reducing errors and } \\
\text { dissatisfaction, improving } \\
\text { work quality and the ability } \\
\text { of individuals to contribute } \\
\text { to institutions. }\end{array}$ & $\begin{array}{l}\text { Online SPPD } \\
\text { improves the quality } \\
\text { of communication } \\
\text { between units and } \\
\text { cooperation between } \\
\text { units. }\end{array}$ & $\begin{array}{l}\text { There is still a Simkug } \\
\text { system that needs to } \\
\text { be integrated with this } \\
\text { online SPPD so that it } \\
\text { can improve work } \\
\text { quality, communication } \\
\text { quality, and system } \\
\text { quality. }\end{array}$ \\
\hline $\begin{array}{l}\text { Service (Hammer \& } \\
\text { Champy, 1993) }\end{array}$ & $\begin{array}{l}\text { The system is made } \\
\text { transparent so that } \\
\text { the progress of the } \\
\text { submission is } \\
\text { known and the user } \\
\text { can know the } \\
\text { process in real time. }\end{array}$ & $\begin{array}{l}\text { Digitization, which is done } \\
\text { in online SPPD, namely the } \\
\text { application file that was } \\
\text { printed online using the } \\
\text { application and the approval } \\
\text { of the supervisor who used } \\
\text { to apply a signature, is now } \\
\text { the approval process by } \\
\text { Online SPPD, as well as } \\
\text { direct tariff validation by } \\
\text { the maker/unit concerned } \\
\text { is no longer manual by the } \\
\text { HR so that the HR service } \\
\text { could be better. }\end{array}$ & $\begin{array}{l}\text { In universities, some } \\
\text { processes will switch } \\
\text { to digitization, one of } \\
\text { which is online SPPD } \\
\text { to make it easier for all } \\
\text { processes to run } \\
\text { smoothly and can be } \\
\text { accessed anywhere, so } \\
\text { that users can get good } \\
\text { service. }\end{array}$ & $\begin{array}{l}\text { In improving services } \\
\text { to users, online SPPD } \\
\text { has provided a } \\
\text { transparent process, } \\
\text { progress can be } \\
\text { accessed in real time, } \\
\text { there is no need for } \\
\text { manual signatures that } \\
\text { require time which can } \\
\text { reduce service to users. }\end{array}$ \\
\hline
\end{tabular}




\begin{tabular}{|l|l|l|l|l|}
\hline \multicolumn{1}{|c|}{ BPR Variable } & \multicolumn{1}{|c|}{ A1 } & \multicolumn{1}{c|}{ C1 } & \multicolumn{1}{c|}{ D1 } \\
\hline $\begin{array}{l}\text { Customer focus } \\
\text { Wisayani et al., } \\
\text { 2014) }\end{array}$ & $\begin{array}{l}\text { With the cascading } \\
\text { by superior 1 and } \\
\text { superior 2, } \\
\text { superiors know the } \\
\text { assignments of } \\
\text { subordinates across } \\
\text { units and can } \\
\text { provide focus on } \\
\text { the progress that } \\
\text { the user goes } \\
\text { through. }\end{array}$ & $\begin{array}{l}\text { The results of this online } \\
\text { SPPD program have been } \\
\text { good and accepted by the } \\
\text { academics at TelU, the } \\
\text { application is easy but there } \\
\text { are still technical problems } \\
\text { or human errors when } \\
\text { submitting SPPD as well as } \\
\text { several facilities that are not } \\
\text { yet in online SPPD such as } \\
\text { the option of } \\
\text { grouping/using private car. }\end{array}$ & $\begin{array}{l}\text { Online SPPD is of } \\
\text { great benefit, both for } \\
\text { individual teams and } \\
\text { institutions because it } \\
\text { really changes the } \\
\text { perspective in solving a } \\
\text { problem. }\end{array}$ & $\begin{array}{l}\text { Online SPPD has been } \\
\text { made as transparent } \\
\text { and as user friendly as } \\
\text { possible so that it } \\
\text { helps superiors to find } \\
\text { out about user } \\
\text { progress and provides } \\
\text { benefits for users or } \\
\text { universities in solving } \\
\text { problems that may } \\
\text { occur in the SPPD } \\
\text { application process. } \\
\text { One thing that still } \\
\text { needs to be added to } \\
\text { this system is the } \\
\text { notification system and } \\
\text { a variety of facility } \\
\text { options. }\end{array}$ \\
\hline
\end{tabular}

Table 6. Qualitative Evaluation of BPR Version 1 Results by Interview

The results of qualitative data processing using Miles and Huberman method for the evaluation of the online SPPD system were also strengthened with the results of a focus group discussion (FGD) which was held between the main key role actors and users of the online SPPD which after analyzing the FGD minutes were as follows:

\begin{tabular}{|c|c|c|}
\hline FGD Results - Evaluation of BPR results & Related BPR variables & Conclusion \\
\hline $\begin{array}{l}\text { Online SPPD makes it easier because of not having to wait for } \\
\text { the queuing process in HR. }\end{array}$ & $\begin{array}{l}\text { - Speed (Hammer \& Champy, } \\
\text { 1993) } \\
\text { - Process acceleration (Widayani } \\
\text { er al., 2014) }\end{array}$ & $\begin{array}{l}\text { Faster processing } \\
\text { time }\end{array}$ \\
\hline $\begin{array}{l}\text { Online SPPD accelerates the processing time for SPPD } \\
\text { submissions from } 10-11 \text { days to } 1-2 \text { days. }\end{array}$ & $\begin{array}{l}\text { - Speed (Hammer \& Champy, } \\
\text { 1993) } \\
\text { - Process acceleration (Widayani } \\
\text { er al., 2014) }\end{array}$ & $\begin{array}{l}\text { Faster processing } \\
\text { time }\end{array}$ \\
\hline $\begin{array}{l}\text { Apart from accelerating processing time which is the main } \\
\text { objective of the program, paper costs have become very } \\
\text { efficient where there has been a reduction of up to } 60 \% \text {. Apart } \\
\text { from this, another related aspect is the existence of concrete } \\
\text { and significant support for the environment where with this } \\
\text { improvement process there has been Paper Waste Management } \\
\text { (reducing paper use) }\end{array}$ & $\begin{array}{l}\text { Cost (Hammer \& Champy, } \\
\text { 1993) Efficiency (Widayani er } \\
\text { al., 2014) } \\
\text { Quality (Hammer \& Champy, } \\
\text { 1993) }\end{array}$ & $\begin{array}{l}\text { - } 60 \% \text { cost } \\
\text { efficient } \\
\text { Strongly support } \\
\text { Waste } \\
\text { Management } \\
\text { (Paper waste) }\end{array}$ \\
\hline $\begin{array}{l}\text { Services for application users provided by the SISFO/PUTI } \\
\text { unit are very helpful for users. } \\
\text { The service of the Simkug System unit for users is very high, } \\
\text { both in officer response time and problem solving time. }\end{array}$ & $\begin{array}{l}\text { - Service (Hammer \& Champy, } \\
\text { 1993) }\end{array}$ & Better service \\
\hline $\begin{array}{l}\text { Online SPPD will reduce the workload of employees such as } \\
\text { CS who previously had to deliver SPPD files. }\end{array}$ & $\begin{array}{l}\text { - Quality (Hammer \& Champy, } \\
\text { 1993) } \\
\text { - Service (Hammer \& Champy, } \\
\text { 1993) }\end{array}$ & $\begin{array}{l}\text { - } \quad \text { More focused CS } \\
\text { - } \quad \text { Better service }\end{array}$ \\
\hline $\begin{array}{l}\text { There is a need for notification to superiors when there is an } \\
\text { SPPD submission that needs to be approved, such as } \\
\text { notification of requests for leave from iGracias to superiors } \\
\text { when an employee applies for leave so it is better if this online } \\
\text { SPPD is not immediately approved, there needs to be } \\
\text { notification. }\end{array}$ & $\begin{array}{l}\text { - Quality (Hammer \& Champy, } \\
\text { 1993) } \\
\text { - Customer focus (Widayani er } \\
\text { al., 2014) }\end{array}$ & $\begin{array}{l}\text { Input for future } \\
\text { improvement (system } \\
\text { apps) }\end{array}$ \\
\hline
\end{tabular}




\begin{tabular}{|l|l|l}
\hline $\begin{array}{l}\text { The SPPD system makes it easy for units related to employees } \\
\text { and users. Initially people have to adapt, but it is better when } \\
\text { compared to offline systems. The desired application is more } \\
\text { user-friendly, if possible the application does not open other } \\
\text { applications. If there is a second stage, it is really monitored so } \\
\text { that the ability of each user is monitored so that the application } \\
\text { is even more effective. }\end{array}$ & $\begin{array}{l}\text { Quality (Hammer \& Champy, } \\
\text { 1993) } \\
\text { Customer focus (Widayani er } \\
\text { al., 2014) }\end{array}$ & $\begin{array}{l}\text { Input for future } \\
\text { improvement } \\
\text { (communication, } \\
\text { system apps) }\end{array}$ \\
\hline $\begin{array}{l}\text { There are still problems with the current online SPPD because } \\
\text { using these } 2 \text { applications SPDD with Simkug system would be } \\
\text { better if they become a continuous application door and no } \\
\text { missed data can be overcome with a new, more integrated } \\
\text { online SPPD system. }\end{array}$ & $\begin{array}{l}\text { Quality (Hammer \& Champy, } \\
\text { 1993) } \\
\text { Customer focus (Widayani er } \\
\text { al., 2014) }\end{array}$ & $\begin{array}{l}\text { Input for future } \\
\text { improvement (system } \\
\text { apps) }\end{array}$ \\
\hline
\end{tabular}

Table 7. Evaluation of BPR Version 1 Results with FGD

Based on Table 7 of the evaluation of the BPR online SPPD version 1 process using the BPR variable, it is known that all the results of the FGD with users indicate that this online SPPD version 1 already has good evaluation results in terms of speed, cost, quality, service and customer focus. This proves that the results of the interviews with key persons and the results of the FGDs have synchronous results and support the validation of the evaluation of the BPR process on the online SPPD version 1. On the one hand, in the results of the FGD evaluation, there are suggestions for improvement in terms of quality and customer focus where users stated that there needs to be an increase in the convenience (being user friendly) and an increase in focus on customers in the form of identifying the relationship between online SPPD operators and users which are expected to be one-door and integrated.

\section{Discussion}

The digitization process in the SPPD process that was previously carried out manually into online SPPD shows a radical change which is an element of BPR, with the improvement of the online SPPD process in this study as one part of the BPR process because there are many processes that have changed radically, especially automation/digitization and decentralization of decisions. The radical changes in the online SPPD submission process in this study are supported by the presence of significant added values in the process, namely the occurrence of transparency/monitoring of the progress of the submission process as well as the reporting capability of the processing time of each process owner (accountability), so that when viewed from the elements $\mathrm{BPR}$, there is an increase in the variable speed in terms of time, quality in terms of increased monitoring and customer focus with transparency that can be monitored by users according to user expectations.

From the results of evaluations carried out both quantitatively and qualitatively in this study in the form of data processing results from interviews or FGDs, it is known that the evaluation of online SPPD is very easy, accelerates the process, work quality and the process of submitting SPPD is better, reduces the workload of employees, can provide maximum service for users because the process is faster, and focuses on the user. However, this online SPPD is not without its shortcomings. There are still some things that need to be improved such as there are still problems with integration with Simkug system, there is no notification and it still needs to be more user-friendly. The improvement of each BPR variable can also be proven from the three tables above. It can be concluded that the process of BPR outcomes quantitatively and qualitatively confirms and reinforces each other that speed, cost, quality, service and customer focus are getting better.

By using the implementation of BPR, especially in evaluating this online SPPD, the team or university environment has started implementing it in units and faculties considering that the university is getting bigger; therefore a fast, effective and efficient service is needed such as the online SPPD process which was originally done manually with the long process turned online with several simplified processes. The faster processing time that was the main objective of the program when it was initiated and defined by Vicerrector II has been well achieved. Within 3 months, with the support of BPR process improvements, the process time acceleration was 2.8 times faster or processing time efficiency was $64 \%$. Other aspects that are theoretically included in the BPR variable have also been 
achieved. $60 \%$ more cost efficient by 2.5 times more efficient; quality increases with digitization and process decentralization (no queues, objectivity of verification of PD cost calculations, monitoring of submission processes/transparency, reporting of process time/accountability); service increased (service processing time is fast, sisfo service is available).

The BPR used in solving SPPD problems at universities is appropriate because according to Hammer and Champy (1993), the objective of conducting BPR is to achieve significant improvements in company performance in the target area by rearranging all processes related to the work flow. BPR is a performance improvement process that uses IT as a process. Steps have been taken to eliminate all activities that have no added value, simplify all aspects of work by being online, integrate all elements in the process and finally automate existing activities.

However, as with the continuous improvement process, input for the Online SPPD System version.1 was also conveyed by informants. According to predictions, the problem is no longer at processing time because it has been resolved. The input is an increase in terms of 1) integration of the 2 Simkug system and SPPD applications that are still offline and intermediated by officers; In the future, this will be resolved with the Application Programming Interface (API) between these applications and 2) notifications to officials who are going through the teaching process. These things form the basis for further improvements to Version.2. The BPR concept has benefits for individuals, teams and institutions. Good communication is needed to collaborate in sharing information, making continuous development towards improvement such as SPPD which is currently under development for stage 2. Saving operational costs, accelerating work processes, reducing errors and dissatisfaction, improving work quality and individual ability to provide contribution to institutions, selecting which parts of the business functions or processes need further analysis and identifying which functions and processes are performing well and being maintained or replacing old processes/products that are considered ineffective with new ones.

\section{Conclusion and Recommendations}

The overall result of the current SPPD process improvement program is that the process is faster, more efficient because the process is not done manually but online and there are several processes that do not provide added value are eliminated. The results of this online SPPD program have been good and accepted by the academics at the university. The application is easy but there are still technical problems or human errors when submitting SPPD as well as some facilities that are not available in online SPPD. There are things that need to be improved from the S-OL program such as the integration between the SPPD and Simkug system applications because two different applications will complicate the SPPD application process, especially the verification process. SPPD application needs to be made collectively to accommodate the implementation of SPPD so that it does not have to be input one by one which will require more time so that it is ineffective and inefficient. The application is able to display reports according to the needs of both the financial and HR departments, the system is immediately locked (approval cannot be changed), if SPPD is returned directly to the SPPD maker, do not return to approval because it will add to the SPPD process and evaluation for future improvements so that Online SPPD can be applied in institutions/companies that do not have this system.

This study provides insight into the reengineering process in higher education institutions in the application of an online-based official trip system, as well as filling the gaps regarding the importance of business processes in education-based organizations. Comprehensive data that show completed information about the business process and in-depth data collection in this study can give new perspective about business process reengineering. It can be used as the tools for the improvement and continuous development of online application that proven there is a radical change in the business process. This online-based official trip system is expected to be able to overcome the obstacles experienced by related units and reduce administrative processing time, so that the process is better managed. In addition, this study is expected to be used as a reference for other higher education institutions that have the same characteristics in implementing the system developed in this study. An empirical study can be carried out in further research on the attitudes of users and stakeholders towards the online SPPD system using the Technology Perceived Behavior method so that evaluation data is obtained from a quantitative perspective and knows its relationship to the performance of each unit and user involved in the SPPD system business process online. 
In conclusion, based on the findings explained above, managers should improve the use of SPPD Online application by creating a more advanced application features that can be fully utilized in providing a more effective and efficient result. Managers can benefit from the findings of this research by considering the elements required in developing a better well-integrated online-based official trip system that results in cost efficiency and effective business processes in the long run, including organizational culture, leadership, and information technology that used for the business process reengineering for SPPD online application continuous development. The result in this study also shown there are still found an application weakness based the business process reengineering that need to be improved by the managerial people which is the integration with the other system and no notification in the application. Both need immediately to repaired and improved by the manager.

The limitation of this study is that the research is conducted in higher education institutions supported with a well-built infrastructure of information, so the result would differ in other institution that has not adapted a well-integrated information system. Further research can be conducted by investigating the application's development after being evaluated based on the recommendation proposed in this research as the reference for the app's sustainable development process.

\section{Declaration of Conflicting Interests}

The authors declared no potential conflicts of interest with respect to the research, authorship, and/or publication of this article.

\section{Funding}

The authors received financial support from Telkom University for the research and publication of this article.

\section{References}

Abdous, M. (2005). Designing a faculty development portal and architecture. Proceedings from The 21st Annual Conference on Distance Teacbing and Learning, Madison, Wisconsin. Retrieved from: http://www.uwex.edu/disted/conference/Resource library/proceedings/05 1966.pdf (Accessed April 2021)

Abdous, M.H. (2011). Towards a framework for business process reengineering in higher education. Journal of Higher Education Policy and Management, 33(4), 427-433. https://doi.org/10.1080/1360080X.2011.585741

Abdous, M.H., \& He, W. (2008). A design framework for syllabus generator. Journal of Interactive Learning Research, 19(4), 541-550.

Adenso-Díaz, B., \& Canteli, A.F. (2001). Business process reengineering and university organisation: A normative approach from the Spanish case. Journal of Higher Education Policy and Management, 23(1), 63-73. https://doi.org/10.1080/13600800020047243

Al-Hattami, A., Almotairy, B., Toraba, O., \& Mahgoub, S. Reengineering and Automation of Business Processes: A Case Study with Universities Travel Request Business Process. International Journal of Science and Research, 8(11), 1033-1043.

Al-Mashari, M., Irani, Z., \& Zairi, M. (2001). Business process reengineering: a survey of international experience. Business Process Management Journal, 7(5), 437-455. https://doi.org/10.1108/14637150110406812

Allen, D.K., \& Fifield, N. (1999). Re-engineering change in higher education. Information Research, 4(3), 4-3.

Attaran, M. (2003). Information technology and business-process redesign. Business process management journal, 9(4), 440-458. https://doi.org/10.1108/14637150310484508

Bennis, W.G., \& Mische, M. (1995). The 21st century organization: Reinventing through reengineering. San Francisco: Jossey-Bass Inc Pub.

Bhaskar, L.H. (2018). Business process reengineering: A process based management tool. Serbian journal of management, 13(1), 63-87. https://doi.org/10.5937/sjm13-13188 
Birnbaum, R. (1988). How colleges work: The cybernetics of academic organizations and leadership. San Francisco: Jossey-Bass Inc Pub.

Burke, G., \& Peppard, J. (1993). Business process redesign: Research directions. Business Change and Reengineering, $1(1), 43-47$.

Chen, S., Ren, G., \& He, M. (2017, March). A quantitative approach to determine a corporate's optimal seat upgrading policy of air travels. In 2017 6th International Conference on Industrial Technology and Management (ICITM) (108-113). IEEE. https://doi.org/10.1109/ICITM.2017.7917905

Creswell, J.W. (2003). A framework for design. Research design: Qualitative, quantitative, and mixed methods approaches (9-11). London: Sage Publications.

Creswell, J.W. (2007). Five qualitative approaches to inquiry. Qualitative inquiry and research design: Choosing among five approaches (2, 53-80). London: Sage Publications.

Davenport, T.H. (1993). Process innovation: reengineering work through information technology. United States: Harvard Business Press.

Davenport, T.H., \& Short, J.E. (1990). The new industrial engineering: information technology and business process redesign. MIT Sloan Management Review. Available at: https://sloanreview.mit.edu/article/the-new-industrial-engineering-informationtechnology-and-business-process-redesign/ (Accessed: October 2020).

Douglas, A., \& Lubbe, B.A. (2006). Identifying value conflicts between stakeholders in corporate travel management by applying the soft value management model: A survey in South Africa. Tourism Management, 27(6), 1130-1140. https://doi.org/10.1016/j.tourman.2005.11.007

Earl, M.J., Sampler, J.L., \& Short, J.E. (1995). Strategies for business process reengineering: evidence from field studies. Journal of Management Information Systems, 12(1), 31-56. https://doi.org/10.1080/07421222.1995.11518069

Educause (2005). Good enough! IT investment and business process performance in bigber education. Available at: http://connect.educause.edu/Library/ECAR/GoodEnoughITInvestmentand/41156?time=1203515704 (Accessed: October 2020).

Elzinga, D.J., Horak, T., Lee, C.Y., \& Bruner, C. (1995). Business process management: survey and methodology. IEEE transactions on engineering management, 42(2), 119-128. https:// doi.org/10.1109/17.387274

Fadel, K.J., \& Tanniru, M. (2005). A knowledge-centric framework for process redesign. Proceedings of the 2005 ACM SIGMIS CPR conference on Computer Personnel Research (49-58). Atlanta, Georgia, USA. https://doi.org/10.1145/1055973.1055984

Gunasekaran, A., \& Kobu, B. (2002). Modelling and analysis of business process reengineering. International journal of production research, 40(11), 2521-2546. https://doi.org/10.1080/00207540210132733

Hammer, M., \& Champy, J. (1993). Business process reengineering. London: Nicholas Brealey.

Harrington, H.J. (1991). The Breakthrough Strategy for Total Quality, Productivity, and Competitiveness. In Business Processes Improvement. New York: McGraw-Hill Inc.

Hengst, M.D., \& Vreede, G.J.D. (2004). Collaborative business engineering: A decade of lessons from the field. Journal of Management Information Systems, 20(4), 85-114. https://doi.org/10.1080/07421222.2004.11045782

Holma, A.M. (2012). Interpersonal interaction in business triads-Case studies in corporate travel purchasing. Journal of Purchasing and Supply Management, 18(2), 101-112. https://doi.org/10.1016/j.pursup.2012.04.002

Johansson, H.J. (1993). Business process reengineering: Breakpoint strategies for market dominance. United States: John Wiley \& Sons.

Kaplan, R.B., Murdock, L., \& Ostroff, F. (1991). Core process redesign. The McKinsey Quarterly, (2), 27-44. 
Kenneth, N., Enefaa, T., \& Deedam-Okuchaba, F.B. (2018). Applying business process reengineering to small and medium scale enterprises (SMEs) in the developing world. European Journal of Computer Science and Information Technology, 6(1), 10-22. Available at: http://www.eajournals.org/wp-content/uploads/Applying-Business-ProcessReengineering-to-Small-and-Medium-Scale-Enterprises-SMES-in-the-Developing-World..pdf (Accessed: October 2020).

Lee, R.G., \& Dale, B.G. (1998). Business process management: a review and evaluation. Business Process Management Journal, 4(3), 214-225. https://doi.org/10.1108/14637159810224322

Lin, F.R., Yang, M.C., \& Pai, Y.H. (2002). A generic structure for business process modeling. Business Process Management Journal, 8(1), 19-41. https://doi.org/10.1108/14637150210418610

Lindsay, A., Downs, D., \& Lunn, K. (2003). Business processes-attempts to find a definition. Information and Software Technology, 45(15), 1015-1019. https://doi.org/10.1016/S0950-5849(03)00129-0

Lowenthal, J.N. (1994). Reengineering the organization: A step-by-step approach to corporate revitalization. The University of Michigan: ASQC Quality Press.

Lucas, T. (2016). The application of business process re-engineering systems to enhance service delivery in the public sector. European Journal of Research in Social Sciences, 4(7), 13-22.

Miles, M.B., \& Huberman, A.M. (1984). Drawing valid meaning from qualitative data: Toward a shared craft. Educational researcher, 13(5), 20-30. https://doi.org/10.3102/0013189X013005020

Okunoye, A., Frolick, M., \& Crable, E. (2006). ERP implementation in higher education: An account of pre-implementation and implementation phases. Journal of Cases on Information Technology (JCIT), 8(2), 110-132. https://doi.org/10.4018/jcit.2006040106

Okunoye, A., Frolick, M., \& Crable, E. (2008). Stakeholder influence and ERP implementation in higher education. Journal of Information Technology Case and Application Research, 10(3), 9-38. https://doi.org/10.1080/15228053.2008.10856139

O’Neill, P., \& Sohal, A.S. (1999). Business Process Reengineering A review of recent literature. Technovation, 19(9), 571-581. https://doi.org/10.1016/S0166-4972(99)00059-0

Penrod, J.I., \& Dolence, M.G. (1992). Reengineering: A Process for Transforming Higher Education. Professional Paper Series, 9. Boulder, Colorade: CAUSE.

Petrozzo, D.P., \& Stepper, J.C. (1994). Successful reengineering. United States: John Wiley \& Sons.

Porter, M.E. (1990). The competitive advantage of nations. Harvard business review, 68(2), 73-93. Available at: https://hbr.org/1990/03/the-competitive-advantage-of-nations (Accessed: October 2020). https://doi.org/10.1007/978$1-349-11336-1$

Prasetyaningrum, D.D., \& Juanita, S. (2018). Rancangan Sistem Informasi Perjalanan Dinas Berbasis Web Studi Kasus: Direktorat Jenderal Sumber Daya Dan Perangkat Pos Dan Informatika. IDEALIS: InDonEsiA journaL Information System, 1(4), 218-223. Available at: http://iom.fti.budiluhur.ac.id/index.php/IDEALIS/article/view/1163 (Accessed: October 2020).

Punch, K.F., \& Oancea, A. (2014). Introduction to research methods in education. Los Angeles: Sage Publications

Rachmawati, S., Retnasari, T., \& Sunarto, S. (2018). Optimalisasi Sistem Informasi Perjalanan Dinas Dalam Meningkatkan Efisiensi Biaya Perusahaan. Jurnal Teknologi Dan Ilmu Komputer Prima (JUTIKOMP), 1(2), 241-249. https://doi.org/10.34012/jutikomp.v1i2.269

Romero, O., \& Abelló, A. (2013, July). Open access semantic aware business intelligence. In European Business Intelligence Summer School (pp. 121-149). Springer, Cham. https://doi.org/10.1007/978-3-319-05461-2_4

Savitri, P., \& Amaliah, I.S. (2017). Rancang Bangun Sistem Perjalanan Dinas Sekretariat DPRD Provinsi Jawa Barat. Infotronik: Jurnal Teknologi Informasi dan Elektronika, 2(1), 55-66. https://doi.org/10.32897/infotronik.2017.2.1.30

Sedarmayanti, H. (2018). Manajemen Sumber Daya Manusia; Reformasi Birokrasi dan Manajemen Pegawai Negeri Sipil. Reflika Aditama, Indonesia. 
Sedianingsih, S.E., Mustikawati, E.F., \& Soetanto, N.P. (2014). Teori dan Praktik Administrasi Kesekretariatan. Prenada Media, Indonesia.

Silvana, M., Fajrin, H., \& Danton (2015). Analisis Proses Bisnis Sistem Pembuatan Surat Perintah Perjalanan Dinas Kantor Regional II PT. Pos Indonesia. Jurnal Nasional Teknologi dan Sistem Informasi, 1(1), 18-22. https://doi.org/10.25077/TEKNOSI.v1i1.2015.18

Silverman, D. (2019). Interpreting qualitative data. London: Sage Publications Limited.

Sungau, J.J., Ndunguru, P.C., \& Kimeme, J. (2013). Business process re-engineering: the technique to improve delivering speed of service industry in Tanzania. Independent Journal of management \& production, 4(1), 208-227. https://doi.org/10.14807/ijmp.v4i1.68

Talwar, R. (1993). Business re-engineering-A strategy-driven approach. Long range planning, 26(6), 22-40. https://doi.org/10.1016/0024-6301(93)90204-S

Taouab, O., \& Issor, Z. (2019). Firm Performance: Definition and Measurement Models. European Scientific Journal, 15(1), 93-106. http://dx.doi.org/10.19044/esj.2019.v15n1p93

Telkom University (2021). Telkom University, PTS Terbaik di Indonesia. Available at: https://telkomuniversity.ac.id/telkom-university-pts-terbaik-di-indonesia/ (Accessed: April 2021).

Terziovski, M., Power, D., \& Sohal, A.S. (2003). The longitudinal effects of the ISO 9000 certification process on business performance. European Journal of operational research, 146(3), 580-595.

https://doi.org/10.1016/S0377-2217(02)00252-7

Valiris, G., \& Glykas, M. (2004). Business analysis metrics for business process redesign. Business process management journal, 10(4), 445-480. https://doi.org/10.1108/14637150410548100

Venkatraman, N. (1994). IT-enabled business transformation: from automation to business scope redefinition. Sloan management review, 35, 73-73.

Vidovic, D.I., \& Vuksic, V.B. (2003). Dynamic business process modelling using ARIS. Proceedings of the 25th International Conference on Information Technology Interfaces (ITI). (607-612), Cavtat, Croatia. IEEE. https://doi.org/10.1109/ITI.2003.1225410

Wisayani, N.L., Kertahadi, \& Riyadi (2014). Analisis Business Process Reengineering Untuk Mengevaluasi, Merekayasa Ulang, Dan Memperbaiki Monitoring Kontrak Pada PT PLN (PERSERO) Dist. Jatim Area Malang. Jurnal Administrasi Bisnis, 8(1), 1-10. Available at: http://administrasibisnis.studentjournal.ub.ac.id/index.php/jab/article/view/344 (Accessed: October 2020).

Wolcott, H.F. (2008). Writing up qualitative research. London: Sage Publications. https://doi.org/10.4135/9781452234878

Wynstra, F., Axelsson, B., \& Van Der Valk, W. (2006). An application-based classification to understand buyer-supplier interaction in business services. International Journal of Service Industry Management, 17(5), 474-496. https://doi.org/10.1108/09564230610689786

Zairi, M. (1997). Business process management: a boundaryless approach to modern competitiveness. Business process management journal, 3(1), 64-80. https://doi.org/10.1108/14637159710161585

Journal of Industrial Engineering and Management, 2021 (www.jiem.org)

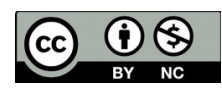

Article's contents are provided on an Attribution-Non Commercial 4.0 Creative commons International License. Readers are allowed to copy, distribute and communicate article's contents, provided the author's and Journal of Industrial Engineering and Management's names are included. It must not be used for commercial purposes. To see the complete license contents, please visit https://creativecommons.org/licenses/by-nc/4.0/. 